\title{
Introduction to the Series
}

The eight books comprising the 'Macmillan Handbooks in Industrial Management' series were from the outset planned as an entity, and together they cover comprehensively yet concisely the varied aspects of knowledge required by those who manage a modern factory or plant. At the same time, care has been taken to ensure that each volume shall be complete in itself, and carry sufficient basic management theory for a proper understanding of its specific subject.

By this means, it has been possible to avoid a common pitfall in the path of many writers on management subjects, namely an attempt to cover all possible ground in one major volume, with varying degrees of success.

By contrast, each author in this series is experienced in the subject of his contribution. A similar pattern has been followed in each book, but each bears the stamp of the personality of its author. Wellestablished principles and tested techniques are explained, but equally new and up-to-date concepts are explored.

It is expected that many practising works managers and mature students will wish to have the whole set on their shelves, but that others will welcome the opportunity of buying single volumes to meet their particular needs.

Thanks are due to the authors for the enthusiasm with which they have joined in the enterprise, and to members of the staff of the Institution of Works Managers for practical support on many occasions.

J. EKINS 


\section{MACMILLAN HANDBOOKS IN INDUSTRIAL MANAGEMENT}

Series Editor: J. EkINs, Cranfield Institute of Technology Executive Editor: A. R. PIRIE, Institution of Works Managers

FINANCIAL CONTROL IN MANUFACTURING

C. N. Aydon

INDUSTRIAL LAW AND ITS APPLICATION IN THE FACTORY Roderick L. Denyer

WORKS ORGANISATION

Alan Lawlor

EMPLOYEE RELATIONS WITHIN THE FACTORY

W. Mitchell with Alan R. Corbett

THE NUMERATE WORKS MANAGER

H. R. Noon

THE CONTROL OF QUALITY

V. G. Parry

PLANT LAYOUT AND MATERIALS HANDLING

A. W. Pemberton

TECHNIQUES FOR PRODUCTION EFFICIENCY

Ken Swann 


\section{Works Organisation}

\section{ALAN LAWLOR}

M.Sc., C.Eng., M.I.Prod.E., A.M.B.I.M., F.I.W.S.P., F.I.S.M.

Macmillan Handbooks in Industrial Management published in association with Macmillan Education 
All rights reserved. No part of this publication may be reproduced or transmitted, in any form or by any means, without permission.

First published 1973 by

THE MACMILLAN PRESS LTD

London and Basingstoke

Associated companies in New York Dublin

Melbourne Johannesburg and Madras

SBN 333145399

The paperback edition of this book is sold subject to the condition that it shall not, by way of trade or otherwise, be lent, resold, hired out, or otherwise circulated without the publisher's prior consent, in any form of binding or cover other than that in which it is published and without a similar condition including this condition being imposed on the subsequent purchaser. 


\section{Contents}

Introduction to the Series 1

Foreword by Richard Marsh 11

Acknowledgements $\quad 13$

1. Introduction 15

Why study works organisations?

Defining the works organisation $\quad 15$

$\begin{array}{ll}\text { The environment } & 17\end{array}$

Kinds of organisation $\quad 17$

$\begin{array}{lr}\text { Problem areas } & 19\end{array}$

People $\quad 19$

Quality $\quad 19$

Maintenance $\quad 19$

$\begin{array}{ll}\text { Production } & 19\end{array}$

The works organisation $\quad 20$

Works management systems $\quad 22$

Service, planning and control 23

How effective are we? $\quad 24$

Education, training and organisational development 25

Summary $\quad 26$

References and other reading $\quad 26$

Check the characteristics of your company 27

2. The Works Organisation 28

The nature of works organisations 28

Economic 28

Technical 28

Social 29

Organisational size $\quad 29$

Organisation charts 31

Job relationships $\quad 34$

Job and task relationships $\quad 34$ 
Objectives

Job descriptions $\quad 37$

Study work $\quad 39$

Summary $\quad 39$

References and other reading 41

3. Manufacturing Systems 42

Historical development $\quad 42$

System characteristics $\quad 42$

Variables in system design $\quad 44$

Production layouts $\quad 44$

Plant size and factory siting $\quad 48$

Decision points $\quad 49$

Summary $\quad 52$

References and other reading $\quad 52$

4. Basic Works Functions 54

General manufacturing characteristics $\quad 54$

Work flow $\quad 55$

Service functions $\quad 56$

Control functions $\quad 57$

Summary $\quad 59$

References and other reading $\quad 59$

5. Production Planning and Control 60

The significant services $\quad 60$

Objectives of production planning and control $\quad 60$

Divisions of production planning and control 61

Interpretation $\quad 62$

Authorisation and order acknowledgement 63

Programming 64

Technical information $\quad 64$

Inventory planning $\quad 65$

Purchasing $\quad 69$

Production capacity $\quad 71$

$\begin{array}{ll}\text { Scheduling } & 72\end{array}$

Controls $\quad 73$

Macro level $\quad 76$

Micro level $\quad 76$

$\begin{array}{ll}\text { Clerical aids } & 76\end{array}$ 
Summary

$\begin{array}{ll}\text { References and other reading } & 79\end{array}$

6. Maintenance and Inspection 81

Objectives of maintenance $\quad 81$

Maintenance terminology $\quad 82$

Maintenance economics $\quad 83$

Reducing down-time $\quad 84$

The maintenance service problem $\quad 84$

Materials and spares $\quad 85$

Maintenance information $\quad 87$

$\begin{array}{ll}\text { Plant analysis } & 90\end{array}$

Plant characteristics $\quad 93$

Maintenance problems $\quad 93$

Inspection $\quad 93$

Technical objectives $\quad 96$

Economic objectives $\quad 96$

The cost of quality $\quad 96$

The factors affecting quality $\quad 97$

Sales and design $\quad 97$

Suitability of throughput materials $\quad 98$

Pre-production planning $\quad 98$

Manufacturing skill $\quad 98$

Work specifications $\quad 98$

Quality standards $\quad 99$

Summary 100

References and other reading $\quad 101$

7. Productivity Evaluation 102

Organisational performance 102

Objective setting $\quad 103$

Efficiency, effectiveness and objectives 104

Overall productivity measurement 105

Basic production indices 107

Work-flow performance $\quad 109$

Inventory performance 109

Facilities maintenance $\quad 110$

Quality performance $\quad 110$

$\begin{array}{ll}\text { Personnel performance } & 110\end{array}$ 
Managerial performance

Summary

8. Problem-Solving

The nature of organisational problems

Problem analysis

Problem- and decision-making definitions

Problem-solving methods

Problem areas

Summary

References and other reading

9. Improving the Organisation

Responding to change

Information about change

Technico-economic

Social

Socio-technical systems

Clarifying objectives

Managerial effectiveness

132

Introducing change

134

Developing understanding

Organisation development

Conclusions

References 


\section{Foreword}

In the world of modern industry, it becomes increasingly necessary for managers to be aware not only of the fundamental principles of good management, but also of the latest techniques necessary for putting those principles into practice.

Works managers in particular, because of the salient position which they hold in the management structure of modern industry and their responsibility for translating policy into execution, must be both educated in sound theory and trained in modern methods.

This series of eight books has been designed to provide the basis of that education and to supplement essential experience.

I welcome the opportunity the Institution of Works Managers has been given to sponsor this venture and commend the books to all present and future managers in industry.

Richard Marsh

Chairman, British Rail

President, Institution of Works Managers 


\section{Acknowledgements}

The writing of any book must inevitably involve self-discipline and organisation, but above all else it is a task that relies on the support and assistance of many people.

My thanks, therefore, go to Jim Ekins, who was instrumental in getting me started, to Tony Pirie for his gentle prodding, and to both of them for their skilful editing. My appreciation also goes to my publisher, without whose efforts this series would not have appeared.

I am indebted to the companies who co-operated in my works organisation investigation and to the many companies who have unknowingly helped me. In addition, my appreciation goes to the writers of the many works quoted as references.

Finally, my thanks go to Jill Sealey for her patience in translating my scribble into the typed draft and to my wife, Nancy, also for her typing assistance and especially for her patience.

A. L. 